\title{
PENGARUH LITERASI DIGITAL, MEDIA SOSIAL, DAN E-COMMERCE TERHADAP KEPUTUSAN BERWIRAUSAHA MAHASISWA
}

\author{
Fernando $^{1}$, Sarwo Edy Handoyo ${ }^{2}$ \\ ${ }^{1}$ Program Studi Manajemen, Fakultas Ekonomi dan Bisnis, Universitas Tarumanagara \\ Email: fernandohandoko1999@gmail.com \\ ${ }^{2}$ Program Studi Manajemen, Fakultas Ekonomi dan Bisnis, Universitas Tarumanagara* \\ Email: sarwoh@fe.untar.ac.id \\ *Penulis Korespondensi
}

Masuk : 02-08-2021, revisi: 15-08-2021, diterima untuk diterbitkan : 30-08-2021

\begin{abstract}
ABSTRAK
Penelitian ini bertujuan untuk mengetahui pengaruh literasi digital, media sosial dan e-commerce terhadap keputusan berwirausaha pada mahasiswa di Jakarta Barat. Sampel yang digunakan dalam penelitian ini sebanyak 75 responden mahasiswa yang sudah menjalani usaha lebih dari 1 tahun di Jakarta Barat dengan teknik purposive sampling. Penelitian ini dianalisis dengan menggunakan bantuan software SmartPLS version 3. Hasil penelitian ini menunjukkan literasi digital memiliki pengaruh positif dan signifikan terhadap keputusan berwirausaha. Sedangkan media sosial dan e-commerce tidak memiliki pengaruh yang signifikan terhadap keputusan berwirausaha.
\end{abstract}

Kata Kunci: Literasi digital, media sosial, e-commerce, keputusan berwirausaha

\section{ABSTRACT}

This study aims to determine the effect of digital literacy, social media and e-commerce on entrepreneurship decisions for students in West Jakarta. The sample used in this study was 75 student respondents who had been in business for more than 1 year in West Jakarta using purposive sampling technique. This research was analyzed using the SmartPLS version 3 software. The results of this study indicate that digital literacy has a positive and significant impact on entrepreneurship decisions. Meanwhile, social media and e-commerce do not have a significant impact on entrepreneurship decisions.

Keywords: digital literacy, social media, e-commerce, entrepreneurship decisions

\section{PENDAHULUAN}

\section{Latar Belakang}

Salah satu cara yang dapat dilakukan untuk mengatasi jumlah pengangguran adalah dengan cara berwirausaha. Indonesia sebagai salah satu negara berkembang juga mengalami masalah pengangguran. Masalah pengangguran terjadi karena peningkatan jumlah penduduk yang diikuti dengan peningkatan jumlah angkatan kerja namun ketersediaan lapangan pekerjaan tidak memadai. Kondisi ini diperburuk dengan adanya pandemi COVID-19 dan pemberlakuan Masyarakat Ekonomi Asean (MEA) yang dimana tingkat persaingan antara lulusan Indonesia dan perguruan tinggi asing semakin tinggi. Banyak orang yang kehilangan pekerjaan selama pandemi COVID19 ini, maka dari itu kita harus bangkit dan mencoba memulai berwirausaha untuk tetap bertahan di masa pandemi COVID-19. Dengan berwirausaha kita dapat membuka lapangan pekerjaan baru bagi masyarakat dan juga dapat meningkatkan perekonomian kita. Menurut (Koe et al., 2015) kewirausahaan didefinisikan sebagai suatu proses dimana orang mengenali peluang, memanfaatkan peluang melalui penemuan dan inovasi, dan akhirnya mendapatkan kepuasan dari itu. Di Indonesia sendiri dari semua penduduk, hanya $3,1 \%$ saja orang-orang yang berwirausaha. Sedangkan negara-negara maju lainnya dapat mencapai $14 \%$ 
(CNN Indonesia, 2018). Literasi digital, Media Sosial, dan E-commerce dapat memudahkan orang-orang dalam berwirausaha. Maka itulah kemunculan media sosial dapat menjadi solusi yang efektif dalam menjalankan usaha berbasis teknologi.

Penelitian yang dilakukan oleh Hasanah \& Khasan, (2019) menunjukkan ada pengaruh secara positif dan signifikan literasi digital terhadap intensi berwirausaha dalam e-business pada mahasiswa Fakultas Ekonomi Universitas Negeri Semarang sebesar 14\%. Hasil penelitian ini juga dilakukan oleh (Bayrakdaroğlu et al 2017) Hasil penelitian ini menunjukkan bahwa literasi keuangan dan literasi digital memiliki pengaruh positif yang signifikan berpengaruh pada niat individu untuk berwirausaha. Penelitian yang dilakukan oleh Mulyandi \& Puspitasari (2018) menyampaikan bahwa Dari hasil analisa data dapat disimpulkan bahwa media sosial berpengaruh cukup kuat dan signifikan terhadap tumbuhnya minat berwirausaha di kalangan generasi muda. Menurut penelitian yang di lakukan oleh Supardi dan Ie (2019) bahwa adopsi $e$ commerce di pada UKM memiliki pengaruh positif terhadap kinerja UKM di DKI Jakarta. Tujuan dari penelitian ini adalah untuk mengetahui pengaruh literasi digital, media sosial, dan $e$ commerce terhadap keputusan berwirausaha pada mahasiswa di Jakarta Barat.

\section{Kajian teori}

Menurut Eisenfuhr (2011) pengambilan keputusan adalah proses membuat pilihan dari sejumlah alternatif untuk mencapai hasil yang diinginkan. Definisi ini memiliki tiga kunci elemen. Pertama, pengambilan keputusan melibatkan membuat pilihan dari sejumlah pilihan. Kedua, pengambilan keputusan adalah proses yang melibatkan lebih dari sekedar pilihan akhir dari antara alternatif. Ketiga, "hasil yang diinginkan" yang disebutkan dalam definisi melibatkan tujuan atau target yang dihasilkan dari aktivitas mental bahwa pembuat keputusan terlibat dalam mencapai keputusan akhir. Menurut Simon (1993) tahap utama dalam proses pengambilan keputusan sebagai berikut: Tahap Pemahaman ( Inteligence Phace )Tahap ini merupakan proses penelusuran dan pendeteksian dari lingkup problematika serta proses pengenalan masalah. Data masukan diperoleh, diproses dan diuji dalam rangka mengidentifikasikan masalah. Tahap Perancangan ( Design Phace )Tahap ini merupakan proses pengembangan dan pencarian alternatif tindakan atau solusi yang dapat diambil. Ini merupakan representasi kejadian nyata yang disederhanakan, sehingga diperlukan proses validasi dan vertifikasi untuk mengetahui keakuratan model dalam meneliti suatu masalah. Tahap Pemilihan ( Choice Phace) Tahap ini dilakukan pemilihan terhadap diantara berbagai alternatif solusi yang dimunculkan pada tahap perencanaan agar ditentukan atau dengan memperhatikan kriteria berdasarkan tujuan yang ingin dicapai. Kerangka pemikiran pada penelitian ini terdapat pada Gambar 1 di bawah ini:

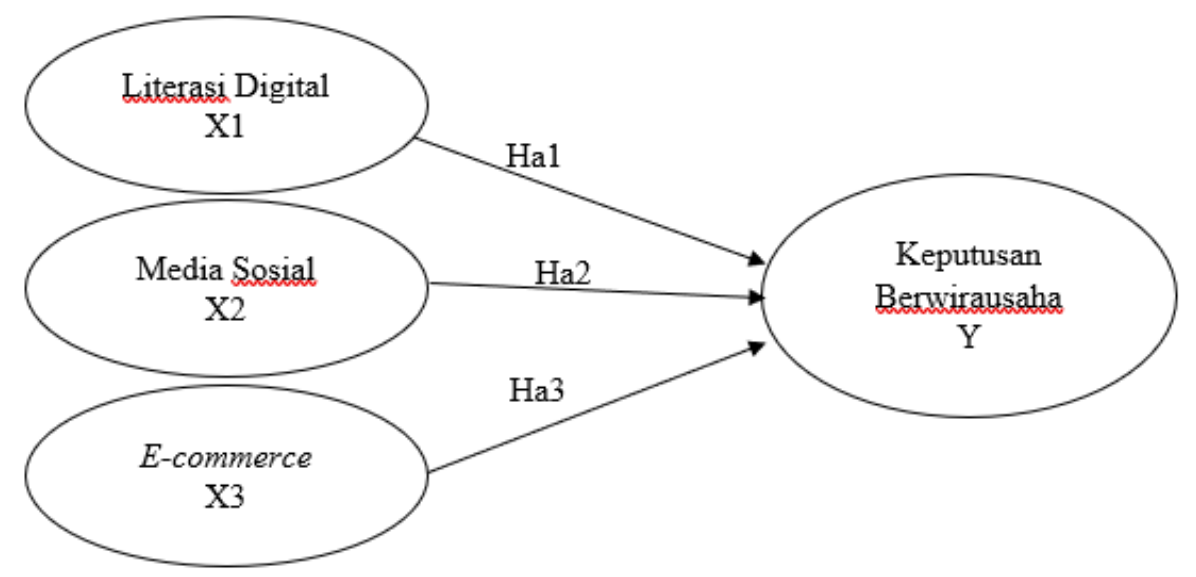

Gambar 1. Kerangka pemikiran 
Hipotesis dalam penelitian ini berdasarkan Gambar 1. di atas adalah : ICT Watch, (2017) mengemukakan bahwa literasi digital adalah kemampuan menggunakan teknologi informasi dan komunikasi (TIK), untuk menemukan, mengevaluasi, memanfaatkan, membuat dan mengkomunikasikan konten atau informasi, dengan kecakapan kognitif maupun teknikal. Yadewani \& Wijaya, (2017) bahwa literasi digital dan pembelajaran bisnis online memiliki berpengaruh signifikan pada niat berwirausaha. Sehingga dapat dirumuskan hipotesis yang pertama berupa

Ha1 : Terdapat pengaruh literasi digital terhadap keputusan berwirausaha pada mahasiswa di Jakarta Barat.

Menurut Cross (2013) Media sosial adalah sebuah istilah yang menggambarkan bermacammacam teknologi yang digunakan untuk mengikat orang-orang ke dalam suatu kolaborasi, saling bertukar informasi, dan berinteraksi melalui isi pesan yang berbasis web. Pengaruh media sosial terhadap kewirausahaan adalah untuk mendukung kinerja pemasaran seiring perkembangan teknologi dan informasi. Media sosial akan mempermudahkan kita dalam mencapai target penjualan. Alfaruk, (2016) Terdapat pengaruh pemanfaatan sosial media pada minat berwirausaha mahasiswa Fakultas Ekonomi Universitas Muhammadiyah Sidoarjo. Media sosial saat ini merupakan trend anak muda untuk mengekspresikan diri menjadi peluang yang sangat besar bagi suatu bisnis untuk dimanfaatkan sebagai media periklanan maupun promosi (Kevin dan Puspitowati 2020). Sehingga dapat dirumuskan hipotesis yang kedua berupa

Ha2 : Terdapat pengaruh media sosial terhadap keputusan berwirausaha pada mahasiswa di Jakarta Barat.

Menurut Laudon \& Laudon, (1998) E-commerce adalah suatu proses transaksi yang dilakukan oleh pembeli dan penjual dalam membeli dan menjual berbagai produk secara elektronik dari perusahaan ke perusahaan lain dengan menggunakan komputer sebagai perantara transaksi bisnis yang dilakukan. Menurut Supardi dan Ie. (2019) Dari beberapa pengertian yang mengarah pada teori para ahli dapat disimpulkan bahwa pengertian e-commerce adalah proses transaksi jual beli serta pemasaran barang dan jasa yang dilakukan melalui internet dimana website digunakan sebagai wadah untuk melakukan proses tersebut. Istiqomah, (2020) dapat disimpulkan bahwa terdapat pengaruh yang positif dan signfikan antara pemanfaatan e-commerce terhadap minat berwirausaha pada mahasiswa AKS-AKK.

Ha3 : Terdapat pengaruh e-commerce terhadap keputusan berwirausaha pada mahasiswa di Jakarta Barat.

\section{METODE PENELITIAN}

Dalam penelitian ini peneliti menggunakan desain penelitian kausal untuk menguji variabel independen terhadap variabel dependen. Desain penelitian disusun untuk mengetahui adanya hubungan sebab dan akibat antar variabel. Dimana variabel independen dalam penelitian ini adalah literasi digital, media sosial, dan e-commerce yang ada hubungan dengan variabel dependen yaitu keputusan berwirausaha. Dimana variabel independen dalam penelitian ini adalah literasi digital, media sosial, dan e-commerce dan variabel dependen adalah keputusan berwirausaha. Populasi yang digunakan dalam penelitian ini adalah mahasiswa yang sudah menjalankan usaha selama minimal 1 tahun dan berada di Jakarta Barat. Teknik pemilihan sampel yang digunakan dalam penelitian ini adalah purposive sampling dengan metode non- 
probability sampling. Dalam penelitian ini memutuskan untuk menggunakan 75 mahasiswa yang sudah menjalani usaha minimal 1 tahun di Jakarta Barat sebagai sampel.

Dalam penelitian ini menggunakan metode Partial Least Square (PLS) versi 3 untuk mengolah dan menganalisis data. Variabel yang akan diteliti dalam penelitian ini adalah literasi digital, media sosial, dan e-commerce sebagai variabel independen dan keputusan berwirausaha sebagai variabel dependen. Handley, (2018) Variabel literasi digital menggunakan indikator mengidentifikasi kebutuhan informasi, menemukan informasi, mengakses informasi, mencari informasi, mengatur informasi secara professional, mengatur informasi secara etis, dan mengaplikasikan informasi. Charoensukmongkol \& Sasatanun, (2017) Variabel media sosial menggunakan indikator mengumpulkan data pelanggan menggunakan media sosial, membedakan pelanggan menggunakan media sosial, mengklasifikasikan pelanggan menggunakan media sosial, berinteraksi dengan pelanggan menggunakan media sosial, memfasilitasi pelanggan menggunakan media sosial, kebutuhan pelanggan menggunakan media sosial, menawarkan produk menggunakan media sosial. Darsono et al., (2019) Variabel Ecommerce menggunakan indikator pemasaran melalui e-commerce, informasi positif $e$ commerce, referensi e-commerce, mencari informasi e-commerce, aplikasi e-commerce. Rudawska, (2020) Variabel keputusan berwirausaha menggunakan indikator, implementasi ide positif, mengontrol pekerjaan sendiri, keinginan menjadi bos, pengakuan eksistensi, mengatur orang lain atau tim, menciptakan masa depan sendiri, kemampuan melakukan hal penting di lingkungan sekitar, dan berasal dari keluarga yang memiliki bisnis. Masing-masing variabel memiliki beberapa indikator dan diukur menggunakan skala Likert dimana terdapat jawaban sangat tidak setuju (STS), tidak setuju (TS), netral (N), setuju (S), dan sangat setuju (SS).

\section{HASIL DAN PEMBAHASAN}

Untuk mengukur nilai convergent validity dapat diukur melalui nilai average variance extracted (AVE) dan nilai dari loading factor. Indikator dapat dikatakan baik jika nilai dari loading factor lebih dari 0,7 maka indikator dapat dikatakan baik, jika dalam tahap pengembangan skala dengan nilai 0,5 hingga 0,6 masih bisa diikut sertakan dalam dalam average variance extracted (AVE), suatu indikator dinyatakan sah jika nilai AVE $\geq 0,5$ (Ghozali, 2015).

Tabel 1. Hasil Uji Average Variance Extracted (AVE)

\begin{tabular}{|c|c|c|}
\hline Variabel & AVE & Keterangan \\
\hline Literasi Digital & 0,565 & Valid \\
\hline Media Sosial & 0,623 & Valid \\
\hline E-commerce & 0,646 & Valid \\
\hline Keputusan Berwirausaha & 0,573 & Valid \\
\hline
\end{tabular}

Selanjutnya hasil pengujian pada analisis reliabilitas pada penelitian ini dapat dilihat pada Tabel 2. Rule of thumb yang digunakan untuk nilai Composite Reliability lebih besar dari 0,7 serta nilai cronbach's alpha lebih besar dari 0,7 (Ghozali \& Latan, 2015, p. 75).

Tabel 2. Hasil Uji Reliabilitas Terhadap 75 Responden

\begin{tabular}{|l|c|c|c|}
\hline \multicolumn{1}{|c|}{ Variabel } & Cronbach's Alpha & Composite Reliability & Keterangan \\
\hline Literasi digital & 0,873 & 0,901 & Reliabel \\
\hline Media sosial & 0,940 & 0,948 & Reliabel \\
\hline E-commerce & 0,868 & 0,901 & Reliabel \\
\hline Keputusan berwirausaha & 0,894 & 0,915 & Reliabel \\
\hline
\end{tabular}


Berdasarkan pengujian inner model, data yang sudah valid dan reliable akan diolah menggunakan uji koefisien determinasi $\left(\mathrm{R}^{2}\right)$, Uji $F$-Square $\left(\mathrm{f}^{2}\right)$, pengukuran $Q$-square $\left(\mathrm{Q}^{2}\right)$ dimana dapat dilihat pada Tabel 3, Tabel 4, dan Tabel 5 di bawah. Sedangkan hasil pengujian hipotesis (path coeffients) dapat dilihat pada Tabel 6. Kemudian hasil uji kecocokan model atau goodness of fit $(\mathrm{GoF})$ dalam penelitian ini memiliki hasil perhitungan sebesar 0,497 maka dapat dikatakan bahwa model penelitian ini memiliki kecocokan yang tergolong besar.

Tabel 3. Hasil Koefisien Determinasi

\begin{tabular}{|c|c|}
\hline Variabel & $\boldsymbol{R}$ Square \\
\hline Keputusan Berwirausaha & 0,275 \\
\hline
\end{tabular}

Berdasarkan Tabel 3 Dapat disimpulkan bahwa 27.5\% dari variabel dependen yaitu keputusan berwirausaha dapat diteliti dengan variabel-variabel yang diteliti pada penelitian ini, sisanya sebesar $72.5 \%$ dapat dijelaskan oleh variabel-variabel lain yang tidak diteliti pada penelitian ini.

Tabel 4. Hasil uji effect size $\left(f^{2}\right)$

\begin{tabular}{|c|c|}
\hline & Keputusan Berwirausaha \\
\hline Literasi Digital & 0,213 \\
\hline Media Sosial & 0,000 \\
\hline E-commerce & 0,022 \\
\hline
\end{tabular}

Berdasarkan data pada Tabel 4 dapat dijelaskan bahwa nilai F-Square (f2) dalam variabel literasi digital terhadap keputusan berwirausaha sebesar 0.213, variabel media sosial terhadap keputusan berwirausaha 0,000 , dan variabel e-commerce terhadap keputusan berwirausaha sebesar 0,022. Hasil 0,213 memiliki pengaruh yang sedang, dan hasil 0,022 memiliki pengaruh yang kecil. Dan hasil 0,000 tidak memiliki pengaruh. Menurut Ghozali \& Latan, (2015) nilai $\mathrm{F}^{2}$ 0,35 memiliki pengaruh besar, 0,15 memiliki pengaruh sedang, dan 0,02 memiliki pengaruh kecil.

Tabel 5. Hasil Pengukuran Q-Square $\left(\mathrm{Q}^{2}\right)$

\begin{tabular}{|c|c|c|c|}
\hline Variabel & SSO & SSE & $\mathbf{Q}^{\mathbf{2}}(=\mathbf{1 - S S E} / \mathbf{S S O})$ \\
\hline Keputusan Berwirausaha & 600.000 & 530.721 & 0,115 \\
\hline Literasi Digital & 525.000 & 525.000 & \\
\hline Media Sosial & 825.000 & 825.000 & \\
\hline E-commerce & 375.000 & 375.000 & \\
\hline
\end{tabular}

Berdasarkan data pada Tabel 5, diketahui bahwa variabel literasi digital, media sosial dan ecommerce memiliki pengaruh sebesar 0.115 terhadap keputusan berwirausaha. Chin, (1998) Nilai Q-Square yang didapatkan 0.02 (kecil), 0.15 (sedang) dan 0.35 (besar). Berdasarkan hasil pengukuruan Q-Square pada Tabel 5 dapat dilihat bahwa variabel Literasi Digital, Media Sosial, dan E-commerce memiliki pengaruh yang kecil terhadap Keputusan Berwirausaha sebesar 0.115

Tabel 6. Hasil Path Coefficient

\begin{tabular}{|l|c|c|}
\hline \multicolumn{1}{|c|}{ Variabel } & $t$-statistics & $p$-values \\
\hline $\mathrm{LD} \rightarrow \mathrm{KB}$ & 2,699 & 0,007 \\
\hline $\mathrm{MS} \rightarrow \mathrm{KB}$ & 0,087 & 0,930 \\
\hline $\mathrm{EC} \rightarrow \mathrm{KB}$ & 0,853 & 0,394 \\
\hline
\end{tabular}

Berdasarkan Tabel 6. Hasil pengujian pada variabel Literasi Digital terhadap Keputusan Berwirausaha memiliki nilai T-Statistik sebesar 2.699 atau P-Values sebesar 0.007 sehingga Ha1 dapat dikatakan diterima. Karena nilai T-Statistic tersebut lebih besar dari 1.96 atau $p$-values 
lebih kecil dari 0.05. Dapat disimpulkan bahwa variabel Literasi Digital memiliki pengaruh yang positif dan signifikan terhadap Keputusan Berwirausaha. Sedangkan nilai variabel media sosial terhadap keputusan berwirausaha memiliki nilai T-Statistic sebesar 0.087 atau P-Values sebesar 0.930 sehingga Ha2 dapat dikatakan ditolak. Dapat disimpulkan bahwa variabel Media Sosial memiliki pengaruh yang tidak signifikan terhadap Keputusan Berwirausaha. Berdasarkan nilai variabel E-commerce terhadap Keputusan Berwirausaha memiliki nilai T-Statistic sebesar 0.853 atau P-Values sebesar 0.394 sehingga Ha3 dapat dikatakan ditolak. Dapat disimpulkan bahwa variabel e-commerce memiliki pengaruh yang tidak signifikan terhadap keputusan berwirausaha.

Berdasarkan Tabel 1 di atas, dapat diketahui nilai dari masing-masing AVE terkait tiap variabel, sehingga dapat diperhitungkan dengan cara

$$
\begin{aligned}
& A V E=\frac{0.565+0.623+0.646+0.573}{4}=0.602 \\
& \text { Maka, } \\
G o F= & \sqrt{\overline{A V E} X \bar{R}^{2}} \\
G o F= & \sqrt{\overline{0.602} \times \overline{0.275}}=0.497
\end{aligned}
$$

Hasil Perhitungan Goodness of Fit (GoF) sebesar 0.497 yang artinya tingkat kecocokan dan kelayakan model penelitian ini dinyatakan besar. Menurut Ghozali (2015) Adapun nilai GoF yang terdiri dari rentang angka 0 hingga 1 , dan dinterpretasikan seolah-olah nilainya 0,1 , maka nilai GoF dianggap kecil jika didapati nilai sebesar 0,1 , jika nilainya 0,25 dianggap sedang, sedangkan jika didapati nilai sebesar 0,36 dianggap besar.

\section{Diskusi}

Hasil pengujian dalam Ha1 menunjukkan bahwa Literasi Digital dalam pengujian $T$ statistics memiliki nilai sebesar 2.699 atau lebih dari 1.96 dan memiliki nilai P-Values sebesar 0.007 atau lebih kecil dari 0.05. Sehingga dapat disimpulkan bahwa variabel Literasi Digital terhadap Keputusan Berwirausaha dalam penelitian diterima karena memiliki arah yang positif dan signifikan. Hal ini sesuai dengan teori pengambilan keputusan dan juga hal ini sesuai dengan penelitian yang dilakukan oleh Yadewani \& Wijaya, (2017) Hasil penelitian menunjukkan bahwa literasi digital dan pembelajaran bisnis online memiliki berpengaruh signifikan pada niat berwirausaha. Hasil ini menunjukan bahwa literasi digital yang lebih tinggi dan pembelajaran bisnis online yang lebih baik akan meningkat niat kewirausahaan online, atau sebaliknya. Sehingga dapat dikatakan Literasi Digital berpengaruh positif dan signifikan terhadap Keputusan Berwirausaha. Hal ini juga sesuai dengan penelitian yang dilakukan oleh Handley, (2018) dimana penelitian tersebut mengatakan bahwa literasi digital mempunyai pengaruh yang signifikan terhadap keputusan berwirausaha.

Hasil pengujian dalam Ha2 menunjukkan bahwa Media Sosial dalam pengujian $T$ statistics memiliki nilai sebesar 0.087 atau kurang dari 1.96 dan memiliki nilai P-Values sebesar 0.930 atau lebih besar dari 0.05. Sehingga dapat disimpulkan bahwa variabel Media Sosial tidak memiliki pengaruh signifikan terhadap keputusan berwirausaha pada mahasiswa di Jakarta barat dan dinyatakan ditolak. Hal ini tidak sesuai dengan teori pengambilan keputusan. Namun hal ini sesuai dengan penelitian yang dilakukan oleh Prasetio, (2020) Berdasarkan hasil analisis pada variabel penggunaan media sosial secara parsial tidak berpengaruh secara signifikan terhadap minat berwirausaha. Dengan demikian variabel penggunaan media sosial tidak berpengaruh secara signifikan dan memiliki hubungan korelasi yang positif terhadap minat berwirausaha. 
Hasil pengujian dalam Ha3 menunjukkan bahwa E-commerce dalam pengujian $T$ statistics memiliki nilai sebesar 0.853 atau lebih kecil dari 1.96 dan memiliki nilai PValues sebesar 0.394 atau lebih besar dari 0.05. Sehingga dapat disimpulkan bahwa variabel $E$ commerce tidak memiliki pengaruh signifikan terhadap keputusan berwirausaha pada mahasiswa di Jakarta barat dan dinyatakan ditolak. Hal ini tidak sesuai dengan teori pengambilan keputusan. Namun hal ini sesuai dengan penelitian yang dilakukan oleh Hardilawati et al., (2019) berdasarkan hasil penelitian ada pengaruh positif tetapi tidak berpengaruh signifikan antara variabel e-commerce pada niat berwirausaha. Hal ini juga sesuai dengan penelitian yang dilakukan Nurabiah et al., (2021) Hasil penelitian menunjukkan bahwa terdapat pengaruh tidak signifikan antara e-commerce terhadap pengambilan keputusan mahasiswa akuntansi dalam berwirausaha.

\section{KESIMPULAN DAN SARAN}

Berdasarkan hasil analisis data dan dilakukan pembahasan diatas, maka kesimpulan dari penelitian ini adalah literasi digital terbukti berpengaruh positif signifikan terhadap keputusan berwirausaha pada mahasiswa di Jakarta Barat. Sedangkan media sosial dan e-commerce memiliki pengaruh yang tidak signifikan terhadap keputusan berwirausaha pada mahasiswa di Jakarta Barat. Selain itu terdapat saran yang sekiranya dapat bermanfaat bagi mahasiswa di Jakarta Barat, maupun bagi penelitian mendatang. Bagi mahasiswa di Jakarta Barat di sarankan untuk meningkatkan kesadaran akan kemajuan teknologi digital untuk dapat melihat peluangpeluang bisnis yang ada. Bagi penelitian mendatang, disaranakan untuk menambah variabel seperti, lingkungan keluarga, industri kreatif, pengetahuan kewirausahaan dan niat berwirausaha sebagai variabel intervening atau mediasi.

\section{REFERENSI}

Alfaruk, M. H. (2017). Pengaruh Pemanfaatan Sosial Media, Motivasi dan Pengetahuan Terhadap Minat Berwirausaha Pada Mahasiswa Ekonomi di Universitas Muhammadiyah Sidoarjo. Jurnal Ekonomi Pendidikan dan Kewirausahaan, 4(2), 164-172.

Bayrakdaroğlu, A., \& Bayrakdaroğlu, F. (2017). A comparative analysis regarding the effects of financial literacy and digital literacy on internet entrepreneurship intention. Journal of Entrepreneurship and Development, Vol. 12 No:2, p. 27-38

Charoensukmongkol, P., \& Sasatanun, P. (2017). Social media use for CRM and business performance satisfaction: The moderating roles of social skills and social media sales intensity. Asia Pacific Management Review, 22(1), 25-34. https://www.sciencedirect.com/science/article/pii/S1029313215301731

Chin, W. W. (1998). The partial least squares approach to structural equation modeling. Modern methods for business research, 295(2), 295-336.

CNN Indonesia. (2018). Hanya 3,1 Persen Penduduk Produktif di RI yang Wirausaha. https://www.gilindonesia.com/ekonomi/20181018210657-92-339664/hanya-31-persenpenduduk-produktif-di-ri-yang-wirausaha

Cross, M. (2013). Social media security: Leveraging social networking while mitigating risk. United States of America. Elsevier.

Darsono, J. T., Susana, E., Prihantono, E. Y., \& Eley, S. K. (2019). Strategic Policies for Small and Medium Businesses in marketing through E-commerce. Entrepreneurship and $\begin{array}{lll}\text { Sustainability } & \text { Issues, } & 7(2),\end{array}$ https://www.lppm.unmer.ac.id/webmin/assets/uploads/lj/LJ202005041588569041683.pdf

Eisenfuhr, F. (2011). Decision making. Academy of Management Review, 19(2), 312-330.

Ghozali, I. (2015). Aplikasi Analisis Multivariate dengan Program IBM SPSS 23. Badan Penerbit Universitas Diponegoro. 
Ghozali, I., \& Latan, H. (2015). Konsep, Teknik, Aplikasi Menggunakan Smart PLS 3.0 Untuk Penelitian Empiris. Badan Penerbit Universitas Diponegoro.

Handley, F. (2018). Developing Digital Skills and Literacies in UK Higher Education: Recent developments and a case study of the Digital Literacies Framework at the University of Brighton, UK. Publicaciones, 48(1), 97-109.

Hardilawati, W. L., Sandri, S. H., \& Binangkit, I. D. (2019). The Role of Innovation and ECommerce in Small Business. International Conference of CELSciTech 2019 - Social Sciences and Humanities Track (ICCELST-SS 2019), 373, 83-87.

Hasanah, U. U., \& Khasan, S. (2019). Pengaruh Literasi Digital, Efikasi Diri, Lingkungan Terhadap Intensi Berwirausaha Mahasiswa Dalam E-Business. Economic Education Analysis Journal, 8(3), 1198-1215.

ICT Watch. (2017). Kerangka Literasi Digital Indonesia. https://internetsehat.id/ict-watch-riliskerangka-literasi-digital-indonesia/

Istiqomah, M. (2020). Pemanfaatan E-commerce Terhadap Minat Berwirausaha Mahasiswa Akademi Kesejahteraan AKK Yogyakarta. Jurnal Socia Akademika, 6(2), 109-115.

Kevin, \& Puspitowati, I. (2020). Pengaruh Penggunaan Media Sosial dan Orientasi Kewirausahaan terhadap Kinerja UMKM. Jurnal Manajerial dan Kewirausahaan, 2(3), 612-620.

Koe, W.-L., Omar, R., \& Sa'ari, J. R. (2015). Factors Influencing Propensity to Sustainable Entrepreneurship of SMEs in Malaysia. Procedia - Social and Behavioral Sciences, 172, 570-577.

Laudon, K. C., \& Laudon, J. P. (1998). Management Information Systems - New Approaches to Organization \& Technology. 5th edition. Prentice Hall Inc.

Mulyandi, M. R., \& Puspitasari., V. A. (2018). Industri kreatif, media sosial, dan minat berwirausaha: Sinergi menuju pembangunan berkelanjutan. National Conference of Creative Industry Universitas Bunda Mulia. https://journal.ubm.ac.id/index.php/ncci/article/view/1192.

Nurabiah, Pusparini, H., \& Mariadi, Y. (2021). E-Commerce Dan Sistem Informasi Akuntansi Sebagai Faktor Pendorong Pengambilan Keputusan Mahasiswa Akuntansi Untuk Berwirausaha. Jurnal Aplikasi Akuntansi, 5(2), 238-253

Prasetio, T. (2020). Analisis Pengaruh Penggunaan Media Sosial, Motivasi Intrinsik, dan Pengetahuan Kewirausahaan Terhadap Minat Berwirausaha Mahasiswa. Jurnal Sekretari \& Administrasi (Serasi), 18(1), 35-46.

Rudawska, I. (2020). What drives youth to become entrepreneurs? An empirical examination. $\begin{array}{lllll}\text { European Research Studies } & \text { Journal, }\end{array}$ https://www.um.edu.mt/library/oar/handle/123456789/77122

Simon, H. A. (1993). Decision making: Rational, nonrational, and irrational. Educational Administration Quarterly, 29(3), 392-411.

Supardi, M. L., \& Ie, M. (2019). Pengaruh Self Directed Learning Dan Adopsi E-Commerce Terhadap Kinerja UMKM Di Jakarta. Jurnal Manajerial dan Kewirausahaan, Volume 1 No. 2 , 290-296.

Yadewani, D., \& Wijaya, R. (2017). Pengaruh E-Commerce Terhadap minat Berwirausaha. Jurnal RESTI (Rekayasa Sistem Dan Teknologi Informasi), 1(1), 64-69. 